UCRL-JC-103705

PREPRINT

\title{
Development of High-Temperature UV-VIS-NIR Spectroscopy for the Measurement of Free Energies of Complexation at Elevated Temperatures
}

\author{
P. Robouch \\ P. Grant \\ R.A. Torres \\ P.A. Baisden \\ R.J. Silva
}

\section{Received by OSTI}

SEP 231991

This paper was prepared for the MRS 14th International Symposium on the Scientific Basis for Nuclear Waste Management

Symposium $P$ Boston, MA November 26-29, 1990

September 26, 1990

This is a preprint of a paper intended forpublication in a joumal orproceedings. Since changes may be made before publication, this preprint is made available with the understanding that it will not be eited or reprodueed without the permission of the author.

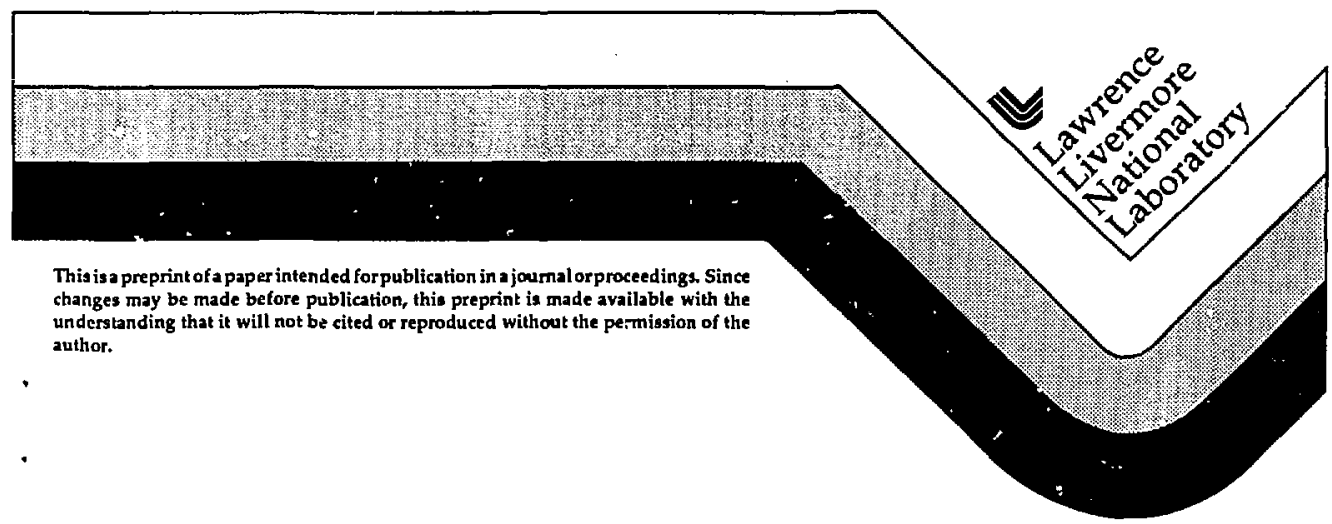




\section{DISCI.AISIER}

This ducument was prepared as an accouns of worh spunsored by an axency the the linited Statev Gover nanent. Nicither the Linited Stutes Gevernanknt nor the L nivervin of Califorais nor any of their enployes, makes anb warranty. evpress ar implied, in evames ang lexal lisbility ne responsibility for the accurary. completenest. me mefolnes of 2 ns infoemulion, ipparalus product, or process disclined. or reprements that its use would anl infringe privalely owned rights. Reference herein in any sparific cummercial peiducis, process, os serice by trade naplt, trademurh, manufecturer, itf riterwise. dies mut necessurils constitule or impls iks endorsemenl, recummendation. af lauring hy the L'nited Sintes Guternmeat nr the linisersity of Colifarnie. The sicw, and opinions of authors expressed befein do nor pecessurils slate of reflect those of thu Laited States Government or the Laivervisy of Califor nia, ynd shull nas hu uwd fat zdertiking or product endersement purpones. 
DEVELOPMENT OF HIGH-TEMPERATURE UV-VIS-NIR SPECTROSCOPY FOR THE MEASUREMENT OF FREE ENERGIES OF COMPLEXATION AT ELEVATED TEMPERATURES

PIOTR ROBOUCH, PAT GRANT, RICHARD A. TORRES, P.A. BAISDEN, AND R.J. SILVA Nuclear Chemistry Dfvision L-234, Lawrence Lfvermore National Laboratory, Livermore, CA 94550 .

\section{ABSTRACT}

We have developed instrumentation capable of measuring optical absorption spectra over a wavelength range of 200-1200 nm and a temperature range of $20-100^{\circ} \mathrm{C}$. This ffber-optic based spectrometer generates data which allow the computation of metal-ligand equilibriun constanes. Studies at five temperatures have been completed using praseodymin-diglycolate as a model system. Fundamental thermodynamic values (free energies, enthalpies, encropies) were obtained from the experimentally-determined stability constants.

\section{INTRODUCTION}

Thermodynamic data pertinent to the interactions of actinides and longlived fission products with groundwater, waste package components, and geologic media are critical input to modeling prograus. While numerous measurements exist for systems at classical thermodynamic temperz tures near $25^{\circ} \mathrm{C},[1]$ the near-field environment of a nuclear repository will experience elevated temperatures ensuing from radiation heating and normal ambient subsurface temperature.[2] Although 25* data are often used for modeling efforts to predict chemical behavior at higher temperatures, the results of these computations are necessarily more uncertain with this approximation. Empirical measurements of free energies and enthalpies at high temperature should provide a more reliable and accurate database for implementation by modeling codes.

We have developed instrumentation capable of uv-vis-nir spectroscopy at elevated temperature while contained in the regulated enclosure of a highlevel radioactivity glovebox. Spectroscopic measurements are performed remotely with fiber-optic probes, and cemperature control of the sample is maintained by a dry-block heater. We chose praseodymium-diglycolate (Prdigly) as the initial chemical system for seudy. From small shifts in wavelength and optical absorption as a function of complexation, metalligand stabflity constants (free energies of reaction) can be calculated under suitable experimental conditions. [3]

We report stability-constant measurements for the Pr-digly complexes at cemperatures of $23,50,65,80$, and $95^{\circ} \mathrm{C}$. The Pr-digly system does not have any direct relevance in modeling the environment of a nuclear repository, but some comparison of the present varfable-temperature results with conventional techniques $[4,5]$ was possible as a primary "proof-ofprinciple."

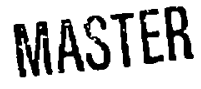


EXFERIMENTAL

\section{Reagents}

Analytical solutions of varying ligand-to-metal (L/M) ratios were prepared from reagent $\mathrm{Pr}_{6} \mathrm{O}_{11}$ [>99.98, Alfa], diglycolic (oxydiacetic) acid [>998, Aldrich], and HClO 4 . Reagent-grade $\mathrm{NaClO}_{4}$ [G.F. Snith] was utilized to adjust each solution to a total fonic strength I $-1.00 \mathrm{M}$. Detalls of solution preparation and neasurements of metal and free-acid concentrations (P[H]) are given elsewhere. [5]

Spectroscopic measurements were made on 13 Pr-digly solutions. The compositions of these solutions (tctal concentrations) were: $[\mathrm{Pr}]_{t}-19.3$ $\mathrm{mM}, 0 \leq[\mathrm{d} f \mathrm{gly}]_{\mathrm{L}} \leq 79.5 \mathrm{mk}, \mathrm{p}[\mathrm{H}]-3.73-4.13$, and $I-1.00 \times\left(\mathrm{NaClO}_{4}\right)$.

\section{Methodology}

The nucleus of the instrumentation is a Guided Wave Model 200 fiberoptle spectrophotometer. [6,7] The unit is capable of singla-beam scanning over the wavelength range $\lambda-200-1200 \mathrm{~nm}$, and two 7-fiber bundle probes transport speccrometer light to and fron a glovebox enclosure over 2-meter lengths of optical cable. Overall systen resolution is noninally $-1 \mathrm{~nm}$. Galibration measurements with NIST prinary-standard wavelangth filters confirmed that spectrometer perfomance was at least $1 \mathrm{~nm}$ from $\lambda-440-740$ nn.

Temperature control of an experinental solution was naintained with a modified Techne model DB-1 Dri-Block heater. The actual temperature of the solution during spectral data acquisition was measured with a teflon-coated thermocouple and display meter (Onega). For the present experiments, $\mathrm{Pr}$ digly absorption data were obtained at $t=(23 \pm 1),(50 \pm 0.6),(65 \pm 0.5)$, $(80 \pm 0.6)$, and $(95 \pm 0.5)^{\circ} \mathrm{C}$. An overpressure of reagent nitrogen was maintalned during all high-temperature experiments to regulate the vapor pressure of water approxinately equivalent to that at $25^{\circ} \mathrm{G}$; maximum overpressure for the present work (at $95^{\circ} \mathrm{C}$ ) was about $180 \mathrm{kPa}$. The acquisition of opelcal absorption data, as well as inscrumental control of the spectrometer, were performed by neans of commercial Guided Wave software running on an IBM XT personal computer.

After a $\mathrm{Pr}$-digly solution was introduced into a quartz optical cell, the unit was closed to the environment. Temperature and pressure settings were adjusted, and the solution was allowed to equilibrate for one hour. Absorbance measurpments between $415-515 \mathrm{~nm}$ were then recorded in $0.05-\mathrm{nm}$ intervals. Normalization of all Pr-digly spectra to a He-Ne 632.8-nm primary calibration filter was made. Scans of the filter were made immediately before and after each solution spectrum, and this normalization procedure successfully corrected for monochromator drift of the spectrometer, which was found to approach $0.5 \mathrm{~nm}$ or more during a system operation of six hours. Adjustment and equilibration of that same solution to the next higher temperature and pressure followed next, with the cycle repeated at each desired temperature. 


\section{Data Analysis}

The Guided Wave data file was imported into Spectra Calc (Galactic Industries Corp.) for processing on an IBM PS $/ 2$. Baseline normalization of each spectrum was accomplished by subtracting a background determined by a linear fit of data in the zero-absorption regions neighboring 415 and 515 nm. All spectral data at a given temperature and a $\lambda$ range of 480-488 nm were then prepared for input to the analysis progran SQUAD. [8] SQUAD computes vaiues of stability constants and extinction coefficients by a matrix regression technique.

For these analyses, only the netal stability conscants were allowed to vary, and the acld constants were flxed at values obtained frow the work of Grenthe and ots. [4] They measured $\log \beta_{011}, 1-1,2$, over the range $5-65^{\circ} \mathrm{C}$. We found these data to be reasonably described by a linear function of $\log \beta$ vs $t$ for both acid species. We therefore extrapolated these functions to obtain values of the cwo acld constants at $t-80$ and $95^{\circ} \mathrm{C}$.

Another aspect of the SQUAD conputations that required novel consideration was the treatment of solution $\mathrm{p}[\mathrm{H}]$ at high temperatures. The total hydrogen inventory of a solution, $H_{t}$, was assumed constant at all remperatures (similar to the inventories of $M_{t}$ and $L_{t}$ ). Known acid constants, experimental $\mathrm{p}[\mathrm{H}]$ values, and measured metal stabilicy constants at $25^{\circ} \mathrm{C}$ were therefore used to calculate $H_{L}$.

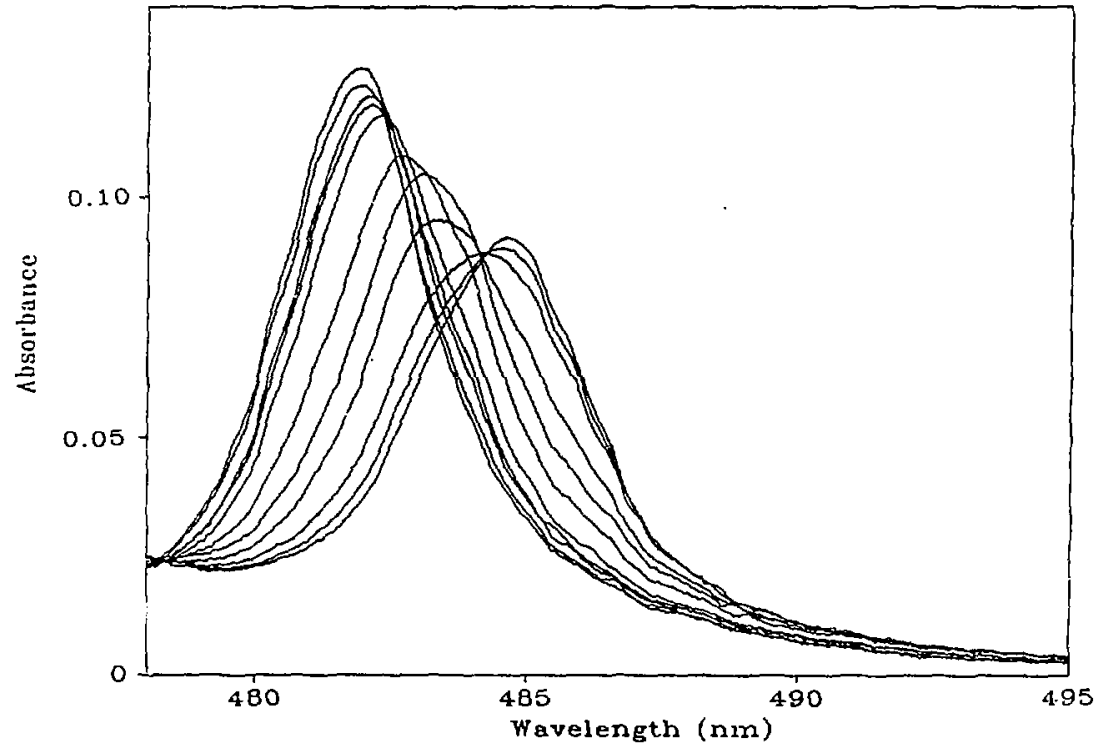

Figure 1. Variation of peak position and intensicy with $L, M$ at constant temperature $\left(50^{\circ} \mathrm{C}\right)$ for the Pr-digly system. Increasing $L / M$ increases spectrum redshift and decreases peak absorption. 


\section{RESULTS AND DISCUSSION}

At any given temperature, as previously observed by other investigators at room temperacure, [9] the absorption spectra exhibited increasing redshift with an increase in wetal conplexation (Figure 1). In the Pr-digly experimental system, three metal-1igand complexes (Pre(digly) ${ }_{1}^{3-21}$ with 1 - 13] and two acid species $\left[H_{j}(d i g l y)^{j-2}\right.$ with $\left.j-1,2\right]$ have been previously observed at $25^{\circ} \mathrm{C} .[1,4]$ The stepulse stability constants measured for the Pr-digly system by the present technique are given in Table 1. Reliable values of the first constant were not obtained at $50^{\circ}$ or $95^{\circ}$. a likely consequence of the limited spectroneter resolution adversely affecting those data sets at the very small redshifts characteristic of the first complex.

Table I. Experimental resules of stepwise stabllity constants at $I$ - $1.0 \mathrm{M}$ for the syster: $\operatorname{PrL}_{1-1}+\mathrm{L}=\mathrm{PrL}_{1}$ for $i-1-3$ and $L$ - diglycolate.

\begin{tabular}{|c|c|c|c|}
\hline$\tau\left({ }^{\circ} \mathrm{C}\right)$ & $\mathrm{K}_{102}$ & $\mathrm{~K}_{102}$ & $\mathrm{~K}_{103}$ \\
\hline 23 & $(2.1 \pm 0.6) \times 10^{5}$ & $(5.0 \pm 2) \times 10^{3}$ & $(5.8 \pm 3) \times 10^{2}$ \\
\hline 50 & - & $(7.1 \pm 2) \times 10^{3}$ & $(4.7 \pm 2) \times 10^{2}$ \\
\hline 65 & $(1.5 \pm 0.9) \times 10^{5}$ & $(6.0 \pm 6) \times 10^{3}$ & $(3.0 \pm 4) \times 10^{2}$ \\
\hline 80 & $(3.2 \pm 1) \times 10^{5}$ & $(4.9 \pm 4) \times 10^{3}$ & $(8.9 \pm 7) \times 10^{1}$ \\
\hline 95 & - & $(1.2 \pm 0.7) \times 10^{4}$ & $(5.0 \pm 3) \times 10^{2}$ \\
\hline
\end{tabular}

All errors given in Table I are 10 values and are those reported by SQUAD. [8] They should thus be considered minimum values associated with these experiments. Comparison of this work with prior literature data is possible at 25 and $50^{\circ} \mathrm{C} .[4,5]$ Within the errors quoted for the present results, agreement of the new technique with established methodology is Judged to be quite satisfactory for the three Pr-digly stability constants. Such agreement serves as a general validation of the present experimental approach.

For the Pr-digly system, existing literature data are consistent with the van't hoff relationship for all three complexes (i.e., ln $\mathrm{K} v \mathrm{~s}^{-1}$ is linear). Reaction enthalples and entropies can thus be calculated, and results of these computations for the three complexes over the range $t-5$. $95^{\circ} \mathrm{C}$ are presented in Table II. 
Table II. Results of van't Hoff analyses of Pr-digly experimental data over the range $t-5-95^{\circ} \mathrm{C}$.

\begin{tabular}{|c|c|c|}
\hline $\begin{array}{c}\text { Complex } \\
\left(\mathrm{PrL}_{\mathrm{l}}\right)\end{array}$ & $\begin{array}{c}-\Delta \mathrm{H}_{101} \\
(\mathrm{~kJ} / \mathrm{mol})\end{array}$ & $\begin{array}{c}\Delta \mathrm{S}_{10 \mathrm{~L}} \\
(\mathrm{~J} / \mathrm{mol}-\mathrm{K})\end{array}$ \\
\hline $\mathrm{i}-1$ & $1.7 \pm 0.3$ & $97 \pm 1$ \\
\hline $1-2$ & $3.5 \pm 0.4$ & $63 \pm 1$ \\
\hline $1-3$ & $4.6 \pm 0.5$ & $33 \pm 2$ \\
\hline
\end{tabular}

\section{ACKNOWLEDGEHENTS}

Prepared by Yucca Mountain Project (MP) participants as part of the Civilian Radioactive Waste Management Progran. The MMP is managed by the Waste Management Project Offlce of the U.S. Department of Energy, Nevada operations office. MMP work is sponsored by the DOE Office of Civilian Radioactive Waste Management.

This work was performed under the ausplees of the U.S. Department of Energy by Lawrence Livermore National Laboratory under Contract W-7405-ENG48 .

\section{REFERENCES}

1. A.E. Martell and R.M. Smich, Critical Stabiliey Constants, 6 vols. (Plenum Press, New York, 1974-1989).

2. D.C. Hoffman and G.R. Choppin, J. Chem. Educ. 63, 1059 (1986).

3. F.R. Hartley, C. Burgess, and R.M. Alcock, Solution Equilibria, (Eliis Horwood, Chichester, 1980). Chapter 8.

4. I. Grenthe and H. Ots, Acta Chem. Scand. 26, 1217 (1972).

5. R.A. Torres, C.E.A. Palmer, P.A. Baisden, R.E. Russo, and R.J. Silva, Anal. Chem. 62, 298 (1990).

6. P. Fitch and A.G. Gargus, Amer. Lab. 17(12), 64 (1985).

7. R.E. Schirmer and A.G. Gargus, Amer. Lab. 1B(12), 30 (1986).

8. D.J. Leggetr, in Computational Methods for the Determination of Formation Constants, edited by D.J. Leggett (Plentm Press, New York, 1985), pp. 159-220.

9. N.K. Davidenko, A.G. Goryushko, and K.B. Yatsimirskii, Russ. J. Inorg. Chem. 18, 943 (1973). 